\title{
An investigation on the optical properties of regioregular Poly(3-Hexylthiophene)
}

- $\operatorname{Lam~Le}^{\mathrm{a}}$

- Anh Tuan Luu ${ }^{\text {b }}$

${ }^{a}$ Materials Technology Key Laboratory, Vietnam National University - Ho Chi Minh City,

${ }^{b}$ Faculty of Materials Technology, Ho Chi Minh City University of Technology - VNU.

(Manuscript Received on October 09 ${ }^{\text {th }}, 2014$; Manuscript Revised November $19^{\text {th }}$, 2014)

\begin{abstract}
Among semiconducting polymers, poly(3optical sensors, smart windows, organic field alkylthiophene)s have attracted great attention and generated many studies over the past few years. Among them, regioregular (head-to-tail) poly(3-hexylthiophene) (P3HT) has been especially investigated due to its superior optoelectronic properties, good solubility in the most common organic solvents, chemical and thermal stabilities and also very low toxicity. These properties enable P3HT to be significantly useful in a large variety of applications such as effect transistors (OFETS), electrochromic devices, and solar cells. Here, we report the synthesis of poly(3-hexylthiophene) (P3HT) and investigate the optical properties of P3HT in different solvents such as chloroform, tetrahydrofuran, toluene, ethylacetate. The structures of P3HT were confirmed by nuclear magnetic resonance $\left({ }^{l} \mathrm{H} N M R\right)$, gel permeation chromatography (GPC), Fourier transform infrared (FT-IR).
\end{abstract}

Keywords. Poly(3-hexylthiophene), GRIM, Conjugated Polymers

\section{INTRODUCTION}

Among rr-P3ATs, regioregular poly(3hexylthiophene) (P3HT) is preferred for many organic electronic applications due to its highest hole mobility, better self-organization compared to other polymers in the series as well as good solubility. The highest hole mobilities in conjugated polymers have to date been observed in P3HT $\left(0.05-0.2 \mathrm{~cm}^{2} / \mathrm{Vs}\right)$ [1-4]. The effects of alkyl side chain length on the electrical, optical and structural properties of P3ATs have extensively been investigated. It has been reported that the field-effect mobility of holes in poly (3-octylthiophene) (P3OT) was similar to that in P3HT, while the value for poly (3dodecythiophene) (P3DDT) was about $10^{-6}$ $\mathrm{cm}^{2} /$ Vs [2]. More recently, the hole mobility varied from $1.2 \times 10^{-3} \mathrm{~cm}^{2} / \mathrm{Vs}$ for poly (3butylthiophene) (P3BuT) and $1 \times 10^{-2} \mathrm{~cm}^{2} / \mathrm{Vs}$ for P3HT to $2.4 \times 10^{-5} \mathrm{~cm}^{2} / \mathrm{Vs}$ for P3DDT.[2] Thus, 
from reported studies on the hole mobility as a function of alkyl chain length, P3HT has been shown to exhibit the highest hole mobility value and hexyl side chain is believed to be optimum for field-effect charge transport, attributed to better self-assembly of P3HT [5]. Consequently, $\mathrm{P} 3 \mathrm{HT}$ has become the most widely investigated material in modern electronic applications.

Moreover, P3HT is commonly chosen as the typical structure for hypothesis testing, such as ways of morphology stabilization of bulk heterojunction thin films and improvement of durability of organic solar cells. P3HT has been used as electron donor, along with fullerence as acceptor, in bulk heterojunction solar cells with power conversion efficiencies up to $5 \%$ and external quantum efficiencies of around $75 \%$. Such high efficiencies have been ascribed to a microcrystalline lamellar stacking of rr-P3HT in the solid state. As a result of this stacking, interchain interactions cause a red shift of the optical absorption. Besides, variance in electrochemical and optical properties as a function of alkyl side chain length has been revealed through comparing those of P3HT with other P3ATs, including P3OT and P3DDT [6] While these polymers exhibit similar energy levels with the optical band gap energy of around $1.9 \mathrm{eV}$, [7-9] slight increases in electrochemical band gaps and decreases in absorption coefficients, due to chromophore dilution (i.e. decrease in conjugated to nonconjugated segment ratio), with increasing side chain lengths have been realized.

\section{EXPERIMENTAL}

\subsection{Materials}

3-Hexyl thiophene, N-bromosuccinimide, iodine, iodobenzendiacetate were purchased from Acros and used as received. $\mathrm{Ni}(\mathrm{dppp}) \mathrm{Cl}_{2}$, i-PrMgCl in tetrahydrofuran (THF) (2 mol/l) were also purchased from Acros and stored in glove box at room temperature. 2Bromoisobutyryl bromide (Br-iBuBr), triethylamine $\left(\mathrm{NEt}_{3} \quad, \quad 99 \%\right), 1,1,4,7,10,10$ hexamethyltriethylenetetramine (HMTETA, 97\%), N,N-dimethylformamide anhydrous (DMF, 99.8\%), sodium borohydride $\left(\mathrm{NaBH}_{4}\right.$, $99 \%)$ and phosphorus(V)oxychloride $\left(\mathrm{POCl}_{3}\right.$, 99\%) were purchased from Aldrich. Copper(I) bromide $(\mathrm{CuBr}, 98 \%)$ was purchased from Fluka and used without further purification. Chloroform $\left(\mathrm{CHCl}_{3}\right.$, Labscan, $\left.99 \%\right)$, toluene (Labscan, 99\%), tetrahydrofuran (THF, Labscan 99\%) were dried using an MBraun solvent purification system under $\mathrm{N}_{2}$. Dichloromethane (Chem-Laboratory, 99.8\%), n-heptane (Labscan, 99\%), n-hexane (Labscan, 99\%) and methanol (Chem-Laboratory, 99.8\%) were used as received. All reactions were performed in ovendried glassware under purified nitrogen.

\subsection{Synthesis of 2-Bromo-3-Hexylthiophene}

To a solution of 3-hexylthiophene $(5 \mathrm{~g}, 29.7$ mmol) in anhydrous THF $(50 \mathrm{ml})$ in a $200 \mathrm{ml}$ flask, a solution of N-bromosuccinimide $(5.29 \mathrm{~g}$, $29.7 \mathrm{mmol}$ ) was added slowly at $0^{\circ} \mathrm{C}$ under nitrogen. The mixture was stirred at $0^{\circ} \mathrm{C}$ for $1 \mathrm{~h}$. After that, $50 \mathrm{ml}$ of distilled water was added to the reaction mixture, and the mixture was extracted with diethyl ether. The organic layer was washed with a solution of $\mathrm{Na}_{2} \mathrm{~S}_{2} \mathrm{O}_{3}(10 \%)$, and then the mixture was washed with a solution of $\mathrm{KOH}(10 \%)$ and dried over anhydrous MgSO4. The mixture was distilled to give a colorless oil. (6.7 g, 92\% yield). ${ }^{1} \mathrm{H}$ NMR (300 $\left.\mathrm{Hz}, \mathrm{CDCl}_{3}\right), \delta(\mathrm{ppm}): 7.19(\mathrm{~d}, 1 \mathrm{H}), 6.82(\mathrm{~d}, 1 \mathrm{H})$, 2.59 (t, 2H), 1.59 (quint, 2H), $1.33(\mathrm{~m}, 6 \mathrm{H}), 0.91$ $(\mathrm{t}, 3 \mathrm{H}),{ }^{13} \mathrm{C}$ NMR $\left(300 \mathrm{~Hz}, \mathrm{CDCl}_{3}\right), \delta(\mathrm{ppm})$ : 
141.0, 128.2, 125.1, 108.8, 31.6, 29.7, 29.4, 28.0, 22.6, 14.1 .

\subsection{Synthesis of 2-Bromo-3-Hexyl-5- Iodothiophene}

Iodine $\quad(1.42 \mathrm{~g}, \quad 11.18 \mathrm{mmol})$ and iodobenzenediacetate $(1.965 \mathrm{~g}, 6.1 \mathrm{mmol})$ were added to a solution of 2-bromo-3-hexylthiophene $(2.5 \mathrm{~g}, 11.1 \mathrm{mmol})$ in dichloromethane $(25 \mathrm{ml})$ at $0^{\circ} \mathrm{C}$. The mixture was stirred at room temperature for $4 \mathrm{~h}$. Then aqueous $\mathrm{Na}_{2} \mathrm{~S}_{2} \mathrm{O}_{3}(10 \%)$ was added, and the mixture was extracted with diethyl ether and dried over anhydrous MgSO4. Then, the solvent was evaporated to obtain a crude product. The residue was purified by silica column chromatography (eluent: $n$-heptane) to give pure 2bromo-3-hexyl-5-iodothiophene as a pale yellow oil. (3 g, 86\% yield). ${ }^{1} \mathrm{H} \mathrm{NMR}\left(300 \mathrm{~Hz}, \mathrm{CDCl}_{3}\right), \delta$ (ppm): 6.97 (s, 1H), 2.52 (t, 2H), 1.56 (quint, 2H), $1.32(\mathrm{~m}, 6 \mathrm{H}), 0.89$ (t, 3H). ${ }^{13} \mathrm{C}$ NMR $(300 \mathrm{~Hz}$, $\mathrm{CDCl} 3), \delta$ (ppm): 144.3, 137.0, 111.7, 71.0, 31.5, 29.6, 29.2, 28.8, 22.5, 14.1 .

\subsection{Synthesis of Regioregular Head-to-tail Poly(3-hexylthiophene) with H/Br End Group}

A dry $500 \mathrm{ml}$ three-neck flask was flushed with nitrogen and charged with 2-bromo-3-hexyl-5iodothiophene (15 g, $40 \mathrm{mmol})$. After three azeotropic distillations by toluene, anhydrous THF (220 ml) was added via a syringe, the mixture was stirred at $0^{\circ} \mathrm{C}$ for 1 hour. i-PrMgCl (2 M solution in THF, $19.14 \mathrm{ml}, 38.28 \mathrm{mmol}$ ) was added via a syringe and the mixture was continuously stirred at $0^{0} \mathrm{C}$ for 1 hour. The reaction mixture was kept cool down to $0^{\circ} \mathrm{C}$. The mixture was transferred to a flask containing a suspension of $\mathrm{Ni}(\mathrm{dppp}) \mathrm{Cl}_{2}(760$ $\mathrm{mg}, \quad 1.4 \mathrm{mmol})$ in THF $(25 \mathrm{ml})$. The polymerization was carried out for 24 hours at $0^{\circ} \mathrm{C}$ followed by addition of a $5 \mathrm{M} \mathrm{HCl}$. After termination, the reaction was stirred for $15 \mathrm{~min}$ and extracted with chloroform. The polymer was precipitated in cold methanol and washed several times with n-hexane. The polymer was characterized by ${ }^{1} \mathrm{H}$ NMR and GPC. Yield is $70 \%$.

FT-IR (cm-1): 721，819，1376，1454，1510, 2853, 2922, 2953. ${ }^{1} \mathrm{H}$ NMR (300 Hz, $\left.\mathrm{CDCl}_{3}\right), \delta$ (ppm): 6.96 (s, 1H), 2.90 (t, 2H), 1.79 (sex, 2H), 1.52 (q, 6H), 0.94 (t, 3H). GPC: $M_{n}=6000 \mathrm{~g} / \mathrm{mol}$. $\mathrm{ĐM}=1.18$.

\subsection{Characterization}

${ }^{1} \mathrm{H}$ NMR and ${ }^{13} \mathrm{C}$ NMR spectra were recorded in deuterated chloroform $\left(\mathrm{CDCl}_{3}\right)$ with $0.003 \%$ TMS as an internal reference, on a Bruker AMX300 apparatus at a frequency of $300 \mathrm{MHz}$ spectrometer. Attenuated total reflection Fourier transform infrared (ATR FT-IR) spectra were recorded using BIO-RAD Excalibur spectrometer equipped with an ATR Harrick Split PeaTM. Size exclusion chromatography (SEC) of P3HT was performed in THF (sample concentration: $1 \mathrm{wt} \%$ ) at $35^{\circ} \mathrm{C}$ using a polymer laboratories (PL) liquid chromatograph equipped with a PL-DG802 degazer, an isocratic HPLC pump LC1120 (flow rate: $1 \mathrm{ml} / \mathrm{min}$ ), a Basic-Marathon Autosampler, a PL-RI refractive index detector and three columns: a guard column PL gel $10 \mu \mathrm{m}$ and two columns PL gel mixed-B $10 \mu \mathrm{m}$. Molecular weight and molecular weight distribution were calculated with reference to polystyrene standards. Data were acquired in continuum mode until acceptable averaged data were obtained.

\section{RESULTS AND DISCUSSION}

Treatment of 2-bromo-5-iodo-3-hexyl thiophene (compound 3, Scheme 1) with 1 equiv. of $\mathrm{iPr}-\mathrm{MgCl}$ results in magnesium-iodine exchange reaction, also referred to as a Grignard metathesis (GRIM) reaction. Then, the "activated monomer" has been polymerized in the presence 
of $\mathrm{Ni}(\mathrm{dppp}) \mathrm{Cl}_{2}$ with an initial monomer-to-nickel molar ratio of 73 . The polymerization has been performed in THF at $0{ }^{\circ} \mathrm{C}$ for $24 \mathrm{~h}$ and quickly terminated by addition of a $5 \mathrm{M} \mathrm{HCl}$ solution to prevent any transhalogenation side-reaction. As determined by gravimetry, a conversion of $70 \%$ has been recorded $\left(M_{n}\right.$ theory $\left.=7280 \mathrm{~g} / \mathrm{mol}\right)$. A good correlation between the theoretical molecular weight $\left(\mathrm{M}_{\mathrm{n}}\right.$ th) and the value determined by gel permeation chromatography (GPC) $\left(\mathrm{M}_{\mathrm{n} \exp }=6000\right.$ $\mathrm{g} / \mathrm{mol}$ ) is obtained attesting for the control over the GRIM polymerization, which is further confirmed by the symmetrical and narrow molecular weight distribution characterized by a low dispersity index $(\mathrm{ĐM}=1.18)$. Figure 1 shows the GPC curve of P3HT synthesized via GRIM.
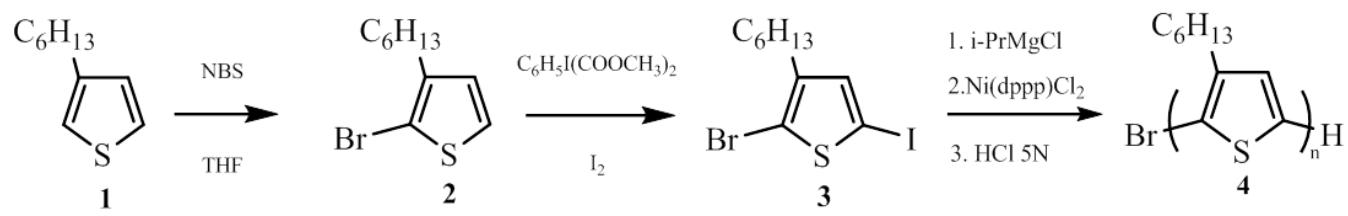

Scheme 1. Synthesis of regioregular poly(3-hexylthiophene) via Grignard metathesis (GRIM) polymerization

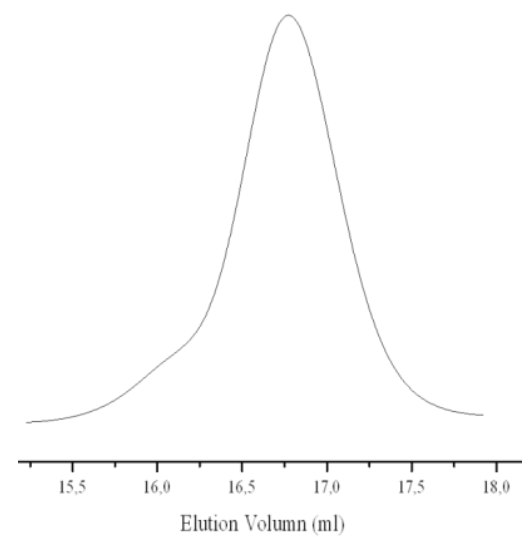

Figure 1. GPC trace of P3HT synthesized by GRIM polymerization.

${ }^{1} \mathrm{H}$ NMR spectra of P3HT provide sensitive probes for substitution pattern in the polymer backbone [10-11]. There are four different chemical signals in a mixture of regioisomers of P3HT (HT-HT/HT-HH/TT-HT/TT-HH) due to the proton at the 4-position of thiophene ring. Reike et al. has shown that the chemical shifts of these four distinct protons are uniquely distinguishable by ${ }^{1} \mathrm{H}$ NMR spectroscopy as in Figure 2. The expanded ${ }^{1} \mathrm{H}$ NMR spectrum of Figure 2 (insert Figure 2) clearly shows the distinct signals at 6.79, 7.00, 7.02 and 7.05 ppm corresponding to the HH-HT, HT$\mathrm{HH}$, TT-HT and TT-HH, respectively, isomers of regiorandom P3HT [12]. 


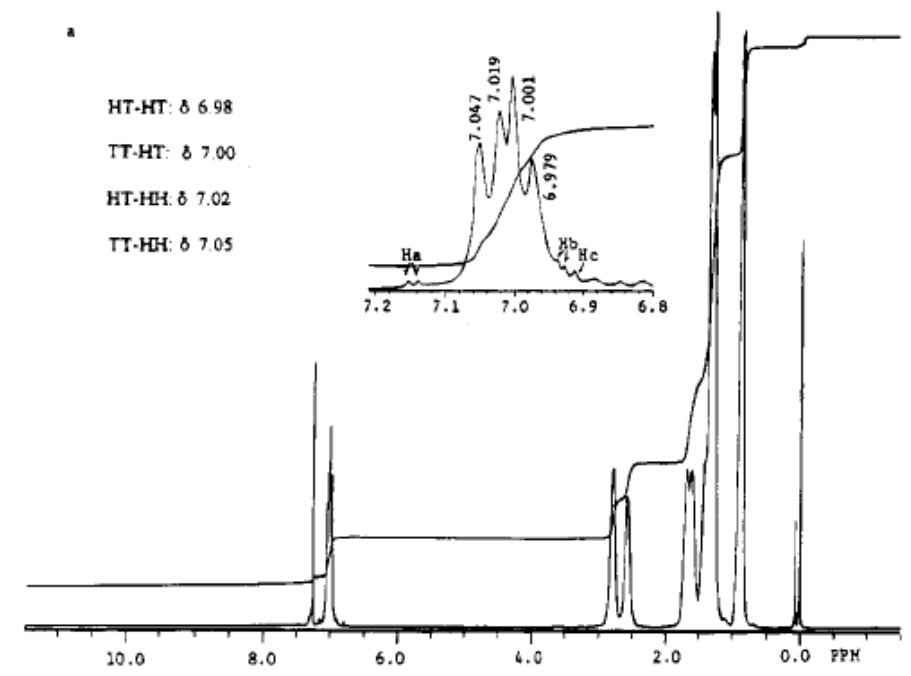

Figure 2. ${ }^{1}$ H NMR spectrum of regiorandom P3HT (taken from reference 12).

In contrast, and in the case of our polymerization, only one sharp peak for thiophene proton is observed in the $1 \mathrm{H}$ NMR spectrum of compound 4 at 6.98 ppm, which denotes the HTHT structure of regioregular P3HT (Figure 3). Besides, a high regioregularity content of $\mathrm{P} 3 \mathrm{HT}$ was determined to be about $99 \%$ from the expanded ${ }^{1} \mathrm{H}$ NMR spectrum in the $\sigma$-methylene proton region. The molecular weight of regioregular P3HT was estimated from ${ }^{1} \mathrm{H}$ NMR is about $6400 \mathrm{~g} / \mathrm{mol}$.

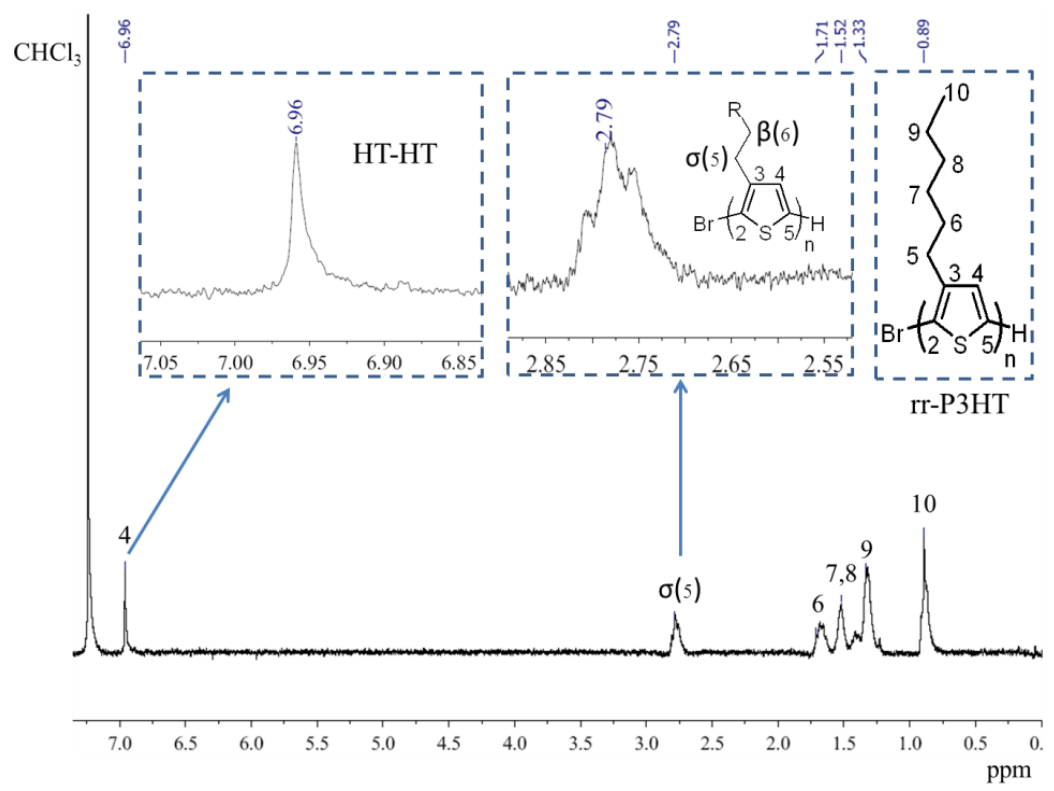

Figure 3. ${ }^{1} H$ NMR spectrum of the synthesized $r$-P3HT (compound 4, scheme 1) 
The optical behaviour of P3HT in solvents of different polarity was studied using UV-vis monitoring the changes in the $\pi-\pi^{*}$ transition of rr P3HT chains. It should be noted that the solubility of the P3HT chains depends on the polarity of the solvent used. Figure 4 shows the absorption of P3HT in different solvents. In the less polar aprotic solvents, THF, chloroform and toluene, the absorption maximum of P3HT is around from $445 \mathrm{~nm}$ to $450 \mathrm{~nm}$. These observations suggest that the regioregular P3HT chains of block copolymers adopt a coil conformation in these solvents. In the case of dichloromethane, the absorption maximum is centered at $460 \mathrm{~nm}$ and a significant broadening of the absorption spectrum is observed in the region from $550 \mathrm{~nm}$ to $650 \mathrm{~nm}$. This observation suggests that a small fraction of regioregular P3HT chains are possibly aggregated in dichloromethane, while the main fraction is still well soluble as the coil conformation. Aggregation is further enhanced in ethyl acetate, where both a main absorption peak at $515 \mathrm{~nm}$ and two vibronic peaks at $560 \mathrm{~nm}$ and $608 \mathrm{~nm}$ are observed with P3HT.

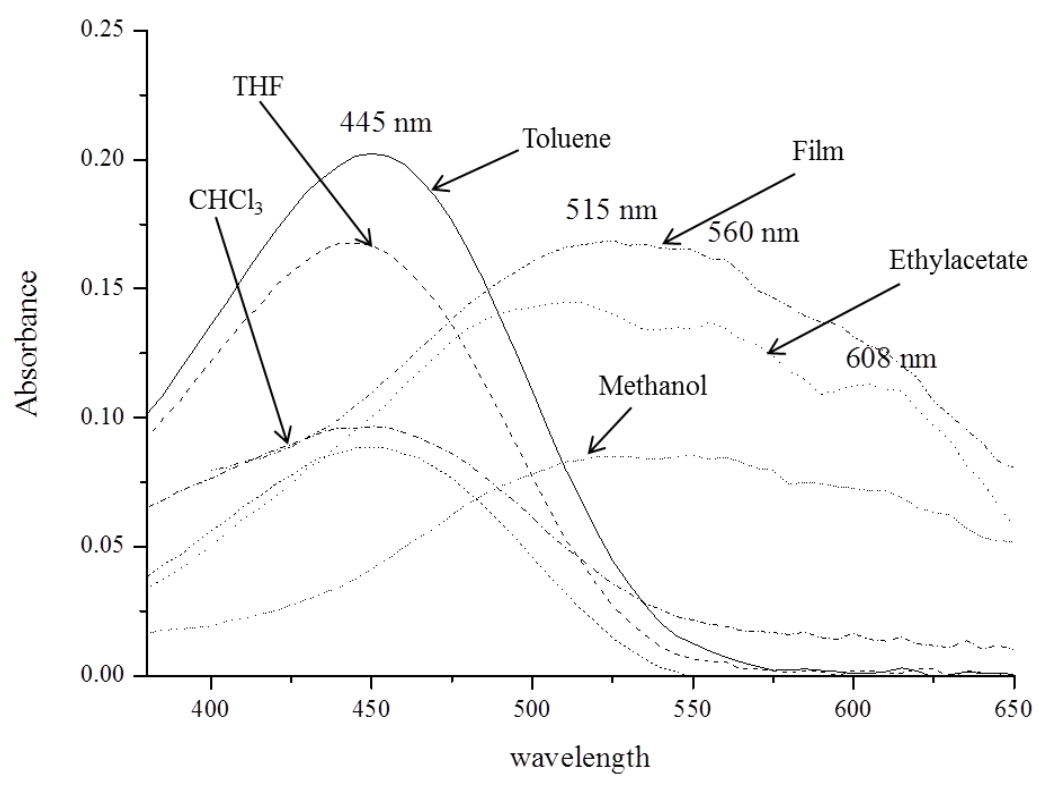

Figure 4. Optical properties of P3HT in different solvents and in solid state film.

\section{CONCLUSIONS}

Perfectly controlled poly(3-hexylthiophene) was synthesized by a 'living' GRIM polymerization. The molecular weight of P3HT was established via the molar ratio of monomer and $\mathrm{Ni}(\mathrm{dppp}) \mathrm{Cl}_{2}$. Moreover, the obtained P3HT shows a narrow polydispersity index. The resulting P3HT was fully characterized by using ${ }^{1} \mathrm{H}$ NMR, GPC, FTIR, and UV-vis which exhibit the regioregular structure of obtained P3HT. Finally, it is worth pointing out that the synthesis of P3HT with control of molecular weights and polydispersity allows for high interest in the fabrication of electronic devices.

Acknowlegments: This research was supported by project "T-CNVL-2014-05" from Ho Chi Minh City University of Technology - Vietnam National University - Ho Chi Minh City, 268 Ly Thuong Kiet, District 10, Ho Chi Minh City, VietNam 


\section{Khảo sát tính chất quang của Poly}

\section{(3-Hexylthiophene) điều hòa}

- Lê Lâm a

- Lưu Tuấn Anh ${ }^{b}$

a PTN Trọng Điểm Công Nghệ Vật Liệu, ĐHQG-HCM

${ }^{\mathrm{b}}$ Trường Đại học Bách Khoa, ĐHQG-HCM

\section{TÓM TÁT}

Trong số những polymer dẫn điện, poly(3alkylthiophene)s được thu hút sự quan tâm và tạo ra rất nhiều ứng dụng nghiên cứu qua những năm gần đây. Trong số đó poly(3hexylthiophene) (P3HT) với cấu trúc điều hòa (đầu nối đuôi) đã được khảo sát sâu sắc nhờ vào tính chất quang-điện đặt biệt của nó, đồng thời $P 3 H T$ còn thể hiện khả năng hòa tan tốt trong những dung môi hữu cơ', bên cạnh đó $P 3 H T$ còn có tính chất bền nhiệt, bền hóa học và it độc hại. Những tính chất trên làm cho P3HT trở nên hữu ích trong những

Từ khóa: Poly(3-hexylthiophene), GRIM

\section{REFERENCES}

[1]. Bao, Z; Dodabalapur, A.; Lovinger, A. J. Appl. Phys. Lett. 1996, 69, 4108.

[2]. Bao, Z.; Feng, Y.; Dodabalapur, A.; Raju, V. R.; Lovinger, A. J. Chem. Mater. 1997, 9, 1299.

[3]. Sirringhaus, H.; Tessler, N.; Friend, R. H. Science. 1998, 280, 1741.

[4]. Wang, G.; Swensen, J.; Moses, D.; Heeger, A. J. J. Appl. Phys. 2003, 93, 6137.

[5]. Babel, A.; Jenekhe, S. A. Synth. Met. 2005, 148,169 .

[6]. Al Ibrahim, M.; Roth, H. K.; Schroedner, M.; Kalvin, A.; Zhokhavets, U.; Gobsch, G.; Scharff, P.; Sensfuss, S. Org. Electron. 2005, 6,65 . ứng dụng rộng như là cảm biến quang, màn hình thông minh, bán dẫn hữu cơ, các thiết bi thay đổi màu sắc quang học và pin năng lượng mặt trời hữu cơ. Trong nghiên cứu này chúng tôi trình bày về quy trình tổng hợp P3HT và khảo sát tính chất quang học của nó trong các hệ dung môi khác nhau. Cấu trúc của P3HT được xác nhận qua phổ cộng hưởng từ hạt nhân ( ${ }^{1} H$ NMR), phồ sắc ký GPC và phổ hồng ngoại FT-IR.

[7]. Ahn, T.; Choi, B.; Ahn, S. N.; Han, S. N.; Lee, H. Synth. Met. 2001, 117, 219.

[8]. Chirvaze, D.; Chiguvare, Z.; Knipper, M.; Parisi, J.; Dyakonov, V.; Hummelen, J. C. Synth. Met. 2003, 138, 299.

[9]. Takahashi, K.; Tsuji, K.; Inote, K.; Yamaguchi, T.; Kanura, T.; Murata, K. Synth. Met. 2004, 130, 177.

[10]. (a) Sato, M.; Morii, H. Macromolecules. 1991, 24, 1196-1200. (b) Sato, M..; Morii, H. Polym. Commun. 1991, 32, 42-44.

[11]. Barbarella, G.; Bongini, A.; Zambianchi, M. Macromolecules. 1994, 27, 3039-3045.

[12]. Chen, T. A.; Wu, X.; Rieke, R. D. J. Am. Chem. Soc. 1995, 117, 233-244. 